\title{
The Role of Principle in Internal Quality Assurance for 4.0 Era in Madarasah
}

\author{
Amiroh Ambarwati ${ }^{1}$, Totok Sumaryanto Florentinus ${ }^{2}$, Rusdarti $^{2}$, Achmad Rifai $^{2}$ \\ \{amirohambarwati@ymail.com ${ }^{1}$ \} \\ ${ }^{1}$ Post Graduate Student Universitas Negeri Semarang, Indonesia \\ ${ }^{2}$ Post Graduate Universitas Negeri Semarang, Indonesia
}

\begin{abstract}
The principal has a very important role in internal quality assurance in Madarasah. The role of school principals in era 4.0 is strongly related to the mastery of digitalization technology that is growing rapidly at this time. The purpose of this paper is to analyze the role of principals in madrasah on internal quality assurance in era 4.0. This research method uses a literate approach, a case study model. Analysis of the case study model has an output concept about the competency of the principal in mastering digitalbased technology, which is used to facilitate the internal quality assurance process in Madarasah. The results of this study, the competency of principals' knowledge of digital development has not been maximally responded, so that the technical mastery of digital technology that is useful in internal quality assurance is not in accordance with quality standards, and the low level of mastery of digital technology cannot be transmitted to educators and educated components in Madarasah that they manage. The conclusion of this paper, shows that the competency of the school principal in mastering the digitalization of technology in the quality assurance process in the Madarasah has an important role in era 4.0, in addition to other supporting competencies. The contribution of this paper is the need to standardize digitalization mastery competencies in quality assurance in Madarasah.
\end{abstract}

Keywords: principles, internal quality assurance, 4.0 era

\section{Introduction}

The development of science and technology becomes a trigger for every individual, to look for new knowledge innovations, new forms of thinking technology that are more effective and efficient, and which can be used to support performance, so that goals can be achieved more optimally, namely human quality, capable of competitiveness global, and technological mastery [1]. The urge to seek innovation, and creation, is needed to support harmony and harmony over the rapid flow of progress, which is increasing (from the era of 1.0 to 4.0 ). This progress becomes a challenge for individuals to immediately improve technology-based human resources, so that the hegemony shown by the new culture, namely the rapid technology, can be utilized in accordance with their respective fields, including in the world of education.

The world of education, namely educational institutions, has an important role in increasing competent and quality human resources. In the 4.0 era, educational institutions have a tough task, that is, they must show their quality more, to realize quality graduates who are able to compete globally, and master the products of technological development [1]. One effort that must be made is the 4.0-based quality assurance system, which is a quality assurance system that uses approaches from paradigm 4.0. 
Paradigm 4.0, requires a complex role, between educational actors at the structural level to the field actors. Government policy, which was stated through, Undang-undang Nomor 20 tahun 2003 (regulation), Peraturan Pemerintah No. 19 tahun 2005 (regulation), Permendiknas Nomor 63 Tahun 2009 (regulation), be a fundamental basis, to determine the direction and steps of 4.0-based ideal quality assurance, which must be carried out by every educational institution especially in Madrasasah, where teachers and principals of Madarasah, have a primary role, in the implementation process. Field actors, namely educators and education staff (especially teachers), and school principals must be able to interpret, and apply government policies in accordance with specified quality standards.

However, the low performance of teachers and principals in Madarasah on quality assurance in Madarasah [2][3],[4], [5], shows things that are paradoxical, where on the one hand the interests of national education want teachers and principals of Madarasah to master the development of science and technology in the $4.0 \mathrm{era}$, on the other hand, teachers and principals of Madarasah are still held hostage by syncretism, where thoughts that don't want accept progressive and global changes. Syncretism is more likely to be conservative and fundamental.

The role of the principal must have double standards for quality assurance in schools. The double standard, in addition to the principal is able to play in accordance with their duties, authority and responsibilities [6], Principals must also have good expectations for their students, provide reinforcement of basic skills for their students, so they can develop well, and be able to create a conducive atmosphere for teachers and employees, and create a comfortable atmosphere for students [7].

Several factors determine the quality of the educational process, including: a) the effectiveness of the principal's leadership style; b) active participation and sense of responsibility of teachers and staff; c) continuity of effective teaching and learning process, d) relevant curriculum; e) have a directed vision and mission; f) a conducive school climate, and g) intrinsic parent and community involvement [8]. In other words, the dominant factor in determining the realization of the quality of education is the principal, both about competence, [4], and performance style. [5], [9]

School principals are also required to be strong leaders, namely explaining the characteristics of resilient principals, namely: a) having far-sighted insights and knowing what actions to take and understanding correctly about the methods to be taken; b) has the ability to coordinate and harmonize all available limited resources; c) has the ability to make decisions, mobilize available resources, tolerance of differences, and d) has the ability to fight the enemies of the principal, namely ignorance, suspicion, not making decisions, mediocracy, imitation, arrogance, waste, rigidity, and duplicity in behaving and acting. [10].

Peraturan Pemerintah Pasal 12 ayat 1 PP 28 Tahun 1990 (regulation) that the principal is responsible for organizing educational activities, school administration, fostering other education personnel, and utilizing and maintaining facilities and infrastructure. Principals are appointed through certain procedures and requirements responsible for the achievement of educational goals through efforts to increase the professionalism of the teaching staff which implies improving learning achievement

Therefore, there needs to be a concept or effort that can be used to help resolve the issue, which is set forth in this study, with a focus on objectives, namely; the role of the principal in the 4.0 era quality assurance in Madarasah, which has the main substance that is the role of ideal competence and the role of mastery of technology to support quality assurance in Madrasah. 


\section{Research Method}

This study used a literature review from some themes. There is teacher challenge from 21 century including the skills which has a relationship with the post critic paradigm (the sophisticated paradigm in the current era). It refers to the uncontrolled and rapid progress of science and technology, it means the theme of education and training should accelerate the development of knowledge and science using the method or complex and an effective model. The outcome of this research is about the idea about education and training in 4.0 era. The idea is adapted in some teacher skills in the 21 century. It can be as the complex delivering method. The data in this research is secondary. It is from the research outcome which is done by the previous researchers. The sources of the data are from the book and the original primary scientific report. Those are from the articles or journals (printed or unprinted). The data has a relationship with the theme and the skill in 21 century. The data analysis used bibliography annotation. The research procedure used the relevant theme of the article organization taken from journal and book. It synthesis with the finding and outcome of the article and identify the important idea. Moreover, it formulated the data which is used as research essence.

\section{Result and Discussion}

\section{a. The Role of Principles in 3.0 Era}

The role of the principal in paradigm 3.0, is as an educator, manager, supervisor, leader, innovator, and motivator. [11]

a. Educator

The principal as an educator, the principal is responsible for guiding teachers, education staff, students, following the development of science and technology, and setting a good example, creating a conducive school climate, giving advice to school members, encouraging all teaching staff, and implementing models interesting learning, forming a culture of teaching and learning conducive. Understanding the role of school principals as educators, does not sufficiently hold on to the definition of educators themselves, but must be interpreted by the meaning of education, educational facilities, and how the education strategy is implemented. For this purpose, the principal must try to instill, promote and enhance at least four kinds of values, namely mental, moral, physical and artistic development. [12]

Creating a conducive school climate requires cooperation or harmonious relations between all school members and is not only the responsibility of the school principal alone. Therefore, efforts that can be made by school principals in improving their performance as educators, especially in improving the performance of teaching staff and learning achievement of participants students are involving teachers in further education by encouraging teachers to start creative and achievement activities [13].

\section{b. As manager}

The principal has functions: planning, coordinating activities, supervising, evaluating activities, holding meetings, making decisions, managing the learning process, organizing administration, and managing administration, students, personnel, facilities, and infrastructure, financing [14]. Principals as managers are required to have readiness to manage schools. To carry out its role and function as a manager, the principal must 
have the right strategy to: a) empower teaching staff through collaboration; b) provide opportunities for educational staff to improve their profession; and c) encourage the involvement of all education personnel who support school programs, because if it refers to the views of modern management, cooperation is a very fundamental thing in an organization [15]

\section{c. As administrator}

the principal is responsible for the smooth running of all work and administrative activities in the school. The principal as a category of education administration must complete the insight of educational leadership with knowledge and anticipatory attitudes towards changes that occur in people's lives, including educational policies [15] .

\section{d. As supervisor}

Supervision is assistance and services provided to teachers so that they want to continuously learn, improve the quality of their learners, foster creativity, improve teachers together with events to select and revise educational goals. [16].

\section{e. As leader}

Principal's leadership is one of the factors that can encourage schools to realize the vision, mission, goals and objectives of the school, through programs that are implemented in a planned and gradual manner. Leadership is the activity of influencing others to want to work to achieve predetermined goals. For this purpose, the principal must be able to influence and mobilize school resources for planning and evaluating school programs, curriculum development, learning, management of resources, learning facilities and resources, finance, student services, school relations with the community, school climate creation, and so on.[4]

\section{f. As innovator}

The principal must have the right strategy to establish a harmonious relationship with the environment, find new ideas, integrate every activity, set an example for all teaching staff in the school and develop innovative learning models.

\section{g. As motivator}

the principal must have the right strategy to motivate the education staff in carrying out various tasks and functions. Because the principal is believed to have the ability to build good motivation will build and increase the effectiveness and efficiency of work [14], [5], so that his subordinates are able to be creative in order to realize good quality education.

\section{b. The Role of Principles in 4.0 Era}

a. As educator with the mastery of digital learning technology

Principals are required to be able to use computer-based learning technology. Computers are tools and applications of information and communication-based technology that are used as the main device for processing data into useful information by processing, presenting, and managing information. Digital learning is not only related to hardware, but 
also includes software in the form of data sent and stored which can be accessed at any time. e-learning which includes static and dynamic web, discussion groups, e-mail, chat, instant messaging, video streaming, animation, application sharing, and video conferencing.[17]

\section{b. As manager with the mastery of digital learning technology}

The principal is able to use information technology, which is used as a system to plan, apply and evaluate every educational activity in the school. Information technology includes hardware components (computers, infrastructure, communication tools, etc.) and software (applications, operating systems, databases, etc.) that must be available to produce a defined information system.[18]

\section{c. As problem solver}

The principal has the ability to solve problems, both from educational problems, as well as social problems that occur in schools. The principal's ability to solve problems, refers to 4 steps, namely: (a) defining the problem; (b) gathering choices; (c) evaluating and making choices; (d) and implementing the problem solve options.

\section{d. $\quad$ Mastery of critical thinking}

The principal has the ability as a person who can think critically. Critical thinking is a process of intellectual discipline that actively and skillfully conceptualizes, applies, analyzes, synthesizes, and / or evaluates information collected from, or generated by, observations, experiences, reflections, reasoning, or communication, as a guide for beliefs and actions. Those are based on universal intellectual values that go beyond material division: clarity, accuracy, precision, consistency, relevance, strong evidence, good reason, depth, breadth, and fairness.

\section{e. As negotiator}

The principal has a strategy as a negotiator or as a reliable conflict manager, using the right strategy. Negoisator is a safety valve, which has the task of being an agent of resolving conflicts of interest that occur in the school environment. Agents of conflict have the role of experts in peace, and promote togetherness. The agent must be able to become a safety valve that must have expertise (1) standing in the middle of neutrality, working on the two conflicting parties in order to reach a meeting point, synthesis agreement, (2) striving for both parties to not lower their dignity and dignity and his self-esteem, (3) striving for both parties to feel beneficial, equally gain and nothing is disadvantaged, (4) strive for both parties to realize that life is dynamic, full of challenges and do not leave together and harmony as a buffer social life.[19]

\section{f. High emotional intelligence}

The principal has the ability to receive, assess, manage, and control his emotions and those around him. Emotional intelligence is the ability of individuals to recognize their own emotions and those of others, distinguish between different feelings and label them appropriately, use emotional information to guide thoughts and behavior, and manage and / or adjust emotions to adapt to the environment or achieve one's goals [20]

\section{g. As creativity}


The principal has the ability to create something new, or new, and or breakthroughs. The school principal is creative, has extensive knowledge and experience, is hard working and has a habit of analyzing SWOT based. SWOT analysis can be applied by analyzing and sorting out various things that affect the four factors, then applying it in the SWOT matrix image, where the application is how strengths are able to take advantage of the opportunities available, how to overcome weaknesses (weaknesses) that prevent the advantages (advantages) of the opportunities (opportunities) that exist, then how strengths (strengths) are able to deal with threats (threats) that exist, and finally is how to overcome weaknesses (weaknesses) that can make threats become threats real or create a new threat.

\section{h. flexibility cognitive}

The principal must have extensive knowledge, in order to be able to make concepts that can be used as a foundation for thinking correctly. The philosophical foundation of the principal based on the paradigm that follows the conditions in the current era. In other words, the principal must think based on longlife thingking, meaning that following the times, not inclined to one thought, but based on several paradigms that develop in the community. A lot of knowledge, can create synthesis of rational thought, objective and in accordance with real conditions.

\section{i. judgement and making decision}

The principal must be able to be a judge of correct decision making. Decision making is a human process that is conscious and encompasses individual and social phenomena, based on the premise of values and facts, concludes a choice between alternatives, with the intention of moving towards something desirable. Decision making is a process of selecting the best alternatives from a number of alternatives systematically to be followed up (used) as a way of solving problems. [21]

Based on the description above, it can be explained that the role of the principal, has undergone a change from the role of the principal in the 3.0 era, to the role of the principal in the 4.0 era. These changes are strongly influenced by factors of the rapid development of science and information technology, which greatly affect the thinking patterns of life of society as a whole. The demands of school principals, in order to be able to harmonize with the needs of the current era, are key to quality assurance in schools / madarasah.

Principals as the main pillars of quality assurance in schools must adapt to conditions in the 4.0 era, in an era, where knowledge and experience, merged with a variety of current information technology, which can support every activity, so that it runs effectively and efficiently. Principal competencies must be increased, from competencies in 3.0 era, to competencies in 4.0 era, by creating 4.0-based quality standardization. Efforts are made is to compile indicators of the quality of 4.0-based principals, which are outlined in government policies, so that they can be realized immediately, towards the quality assurance of 4.0-based principals in Madrasasah.

\section{Conclusion}

Changes in the role of school principals in Madarasah towards era 4.0, must be taken seriously. Era 4.0 is an era that emphasizes information technology, which can be used by principals to perform roles as education, management roles, which are digital based, as well as 
roles as critics, creativists, problem solvers, nogosiators and decision makers who are fast and precise. Quality assurance in the 4.0 era is important, because it is adapted to the development of life at this time, or the role of the principal is still a paradox.

\section{References}

[1] D. M. Kanematsu, H., \& Barry, "STEM and ICT Education in Intelligent Environments," in Springer International Publishing Switzerland, 2016.

[2] Y. Mulyana, "Peran Kepala Sekolah Dasar dalam Pengembangan Profesionalisme Guru," J. Kependidikan Triadik, 2009.

[3] rusdarti dan sucihatiningsih DWP, "Akuntabilitas Penjaminan Mutu Terhadap Akreditasi Program Studi di Pascasarjana Universitas Negeri Semarang," Educ. Manag., vol. 6, no. 2, pp. 196-207, 2017.

[4] M. Fitrah, "PERAN KEPALA SEKOLAH DALAM MENINGKATKAN MUTU PENDIDIKAN," J. Penjaminan Mutu, 2017.

[5] S. Purwanti, "Peran Kepemimpinan Kepala Sekolah Dalam Meningkatkan Disiplin Kerja Guru Dan Pegawai Di SMA Bakti Sejahtera Kecamatan Kongbeng Kabupaten Kutai Timur," eJournal Adm. Negara, 2013.

[6] A. R. dan Y. Purwanti, K., Murniati, "Kepemimpinan Kepala Sekolah Dalam Meningkatkan Kompetensi Guru Pada SMP Negeri 2 Simeulue Timur," J. Ilm. Didakt. XIV, vol. 2, pp. 390-400, 2014.

[7] D. Rosyada, Paradigma Pendidikan Demokratis, Sebuah Model pelibatan Masyarakat dalam Pendidikan. Jakarta: Prenada Media., 2013.

[8] D. \& B. Townsend, Your Child's Scholl. New York: A Plime Book, 1993.

[9] S. Setyati, "Pengaruh Kepemimpinan Kepala Sekolah , Motivasi Kerja dan Budaya Sekolah Terhadap Kinerja Guru,” J. Pendidik. Teknol. Dan Kejuru., 2014.

[10] P. Slamet, Manajemen Berbasis Sekolah. Jurnal Pendidikan dan Kebudayaan. Jakarta: Departemen Pendidikan Nasional, 2000.

[11] M. E, Menjadi kepala sekolah profesional dalam konteks menyukseskan MBS dan KBK. Bandung : Remaja Rosdakarya, 2003, 2003.

[12] M. E, Menjadi kepala sekolah profesional, 2nd ed. Bandung: Remaja Rosdakarya, 2003, 2005.

[13] V. Rusmawati, "Peran Kepemimpinan Kepala Sekolah Dalam Upaya Meningkatkan Disiplin Kerja Guru Pada Sdn 018 Balikpapan," eJournal Adm. Negara, 2013.

[14] S. Sabirin, "Perencanaan Kepala Sekolah Tentang Pembelajaran," J. Tabularasa PPS UNIMED, vol. 9, no. 1, pp. 111-128, 2012.

[15] S. Sunarto, "Pengaruh Gaya Kepemimpinan Kepala Sekolah, Manajemen Berbasis Sekolah dan Iklim Organisasi Terhadap Kepuasan Kerja dan Kinerja Guru SMP di Wilayah Sub Rayon 04 Kabupaten Demak," J. Anal. Manaj., vol. 5, no. 1, 2011.

[16] S. Sagala, Kemampuan profesioanal guru dan tenaga kependidikan. Bandung: CV. Alfabeta, 2010.

[17] Munir, Pembelajaran Digital. Bandung: CV. Alfabeta, 2017.

[18] R. E. INDRAJIT, MANAJEMEN SISTEM INFORMASI DAN TEKNOLOGI INFORMASI.

http://scholar.google.co.id/scholar_url?url=http://repository.unand.ac.id/18152/1/Mana jemen\%2520Sistem\%2520Informasi.pdf\&hl=en\&sa=X\&scisig=AAGBfm2CdDagYfS ogD7iil3xjetdEgOhPg\&nossl=1\&oi=scholarr.

[19] S. A. S. Sidik Puryanto, Ahmad Hariyadi, "PEMAHAMAN (LEARNING TO KNOW) KONFLIK DAN MALFUNGSI AGEN SEBAGAI SUBSTANSI 
PENDIDIKAN KONFLIK DALAM KASUS KONFLIK PABRIK SEMEN DI REMBANG JAWA TENGAH,” J. Penelit. Pendidik., vol. 10, no. 1, 2018.

[20] A. Colman, A Dictionary of Psychology (3 ed.). Oxford University Press, 2008.

[21] J. A. F. Stoner, Management. New Jersey: Englewood Cliffs, Printice Hall, Inc., 1982. 